\title{
Pierre Laforgue, 1848 dans les Fleurs du Mal: Histoire, politique et modernité chez Baudelaire
}

\section{Ida Merello}

\section{(2) OpenEdition}

1 Journals

\section{Edizione digitale}

URL: http://journals.openedition.org/studifrancesi/8991

DOI: 10.4000/studifrancesi.8991

ISSN: 2421-5856

\section{Editore}

Rosenberg \& Sellier

\section{Edizione cartacea}

Data di pubblicazione: 1 octobre 2008

Paginazione: 481

ISSN: 0039-2944

\section{Notizia bibliografica digitale}

Ida Merello, «Pierre Laforgue, 1848 dans les Fleurs du Mal: Histoire, politique et modernité chez

Baudelaire», Studi Francesi [Online], 155 (LII | II) | 2008, online dal 30 novembre 2015, consultato il 11 janvier 2021. URL: http://journals.openedition.org/studifrancesi/8991 ; DOI: https://doi.org/10.4000/ studifrancesi.8991

Questo documento è stato generato automaticamente il 11 janvier 2021.

\section{(c) (1)}

Studi Francesi è distribuita con Licenza Creative Commons Attribuzione - Non commerciale - Non opere derivate 4.0 Internazionale. 


\title{
Pierre Laforgue, 1848 dans les Fleurs du Mal: Histoire, politique et modernité chez Baudelaire
}

\author{
Ida Merello
}

\section{NOTIZIA}

PIERRE LAFORGUE, 1848 dans les Fleurs du Mal: Histoire, politique et modernité chez Baudelaire, «Histoires littéraires», n. 31, juill-août-sept. 2007, pp. 25-38.

1 L'A. intende mostrare come la presenza del 1848 nelle Fleurs sia imprescindibile da un rapporto con i fatti del 1851, del 1857 e del 1861. Per indagarne le allusioni cerca conferma nella produzione saggistica del poeta, in particolare nella critica d'arte, e nella prefazione a Poe. Rintraccia così un'ambivalenza enunciativa confermata nel movimento di trasgressione e di richiamo all'ordine delle Fleurs, e misura lo scarto tra l'atteggiamento politico del Quarantotto e quello del Cinquantasette, in cui il disincanto non gli impedisce di conservare nel testo un residuo sovversivo. Il rimaneggiamento del 1861 mette nettamente in rapporto 1848 e 1851, in una nuova prospettiva di disaffezione ideologica e di crisi del soggetto lirico, dove ogni richiamo agli ideali del Quarantotto risulta un feticcio ormai privo di significato. 